\title{
The Political Economy of Merchandisation of Votes in Nigeria: The Case of 2018 Ekiti Gubernatorial Elections
}

\author{
Oluwasuji Clement Olawole, $\mathrm{PhD}$
}

Political Science and Public Administration Department, Faculty of Social and Management Sciences, Adekunle Ajasin University, Akungba Akoko, Ondo state, Nigeria

DOI: $\underline{10.36348 / \mathrm{sjhss} .2020 . \mathrm{v} 05 \mathrm{i} 02.007}$

| Received: 18.02.2020 | Accepted: 25.02.2020 | Published: 29.02.2020

*Corresponding author: Oluwasuji Clement Olawole

\section{Abstract}

Nigeria's democratic experiment has come a long way. Just like any other political entities, the electoral experience is not without some teething challenges such as ballot box snatching, violence, rigging, etc. in the recent times, a new electoral challenge has just been added into the political lexicon: merchandisation of votes otherwise called vote buying and vote selling. A situation whereby votes are commoditized and political gladiators curry political favor from the electorates by devising series of monetary strategies to win elections; while the electorates also sell their votes to meet their financial lack. Investigating the preponderance of merchandisation of votes in the Nigeria's forth republic, the paper focused on the just concluded July 14, 2018 gubernatorial elections in Ekiti state, Nigeria. Rational choice theory, a variance of Political Economic Approach (PEA) was handy as the foundational basis of the paper. The paper also used contextual analysis source of data collection as the instrument of investigation in other to extrapolate the electoral challenge. It is observed that the politicians and political gladiators embarked on vote buying as a desperate strategy to win elections, so as to gain the plenipotentiary power to authoritatively allocate state resources/values. The electorates on the other hand, sell their votes, because they see it as a way of getting their own share from the politicians who seldom forgetting them after the elections; because of poverty, lacks, famine, in other words, lack of basic family needs; unemployment, illiteracy etc. as some of fundamental reasons for selling their votes. This menace is not without some socio-political and economic implications on the political system. However, the paper observed that to checkmate the merchandisation of vote in Nigeria, certain proactive strategic options are needed such as behavioral and attitudinal change, poverty reduction or eradication schemes, socio-political education, economic empowerment, provision of gainful employment etc. as part of strategic options to ameliorate or eradicate the menace in Nigeria.

Keywords: Elections, Merchandisation, Vote-Buying and Vote-Selling, Rational Choice Theory.

Copyright @ 2020: This is an open-access article distributed under the terms of the Creative Commons Attribution license which permits unrestricted use, distribution, and reproduction in any medium for non-commercial use (NonCommercial, or CC-BY-NC) provided the original author and source are credited.

\section{INTRODUCTION}

As the largest and most populous Black Country in Africa, Nigeria is blessed with large arable of land and all sorts of mineral resources. Yet, right into twenty first century, Nigeria cannot feed her citizens, just as it is economically and technologically backward. The country's indebtedness and poverty has reached such an alarming state that it has become one of the poorest countries in the world. In spite of the heavy annual budgets at all levels of government over the years, the conditions of life of the masses have not shown any remarkable improvement [1].

The above statement captures the epitome of the Nigeria's state in the present century. Miffed with Nigeria's developmental crisis, Osaghae [2], in the preface to the "The Crippled Giant" asked series of questions about the problem with Nigeria. In his quest: what exactly is the trouble with Nigeria? Why did a country once regarded as the giant and hope of Africa because of its immense human and material resources founder so badly? How did a country which many called an exception to the tragedy that had befallen post-colonial state in Africa become like "any other African country?" What could be the trouble with a country which was on a par with Malaysia and Indonesia in the 1960 and now one of the world poorest fifteen countries? Could it be pervasive corruption and gross mismanagement? The enormous problem with Nigeria has made Osaghae to refer to her as "The Crippled Giant". He explained that it was crippled from the beginning by the nature of its colonial creation and integration into the global economy and has remained 
crippled by corrupt and authoritarian regimes, inability to overcome its division, and the inability to determine its destiny in the face of a hegemonic world order and its failure to realise its vast potential. Achebe [2] was more succinct in his view about the human endowment of Nigeria. He contends:

I believe that Nigeria is a nation favoured by providence. I believe there are individuals as well as nations who, on account of peculiar gifts and circumstances, are commandeer by history to facilitate mankind's advancement. Nigeria is such a nation. The vast human and material wealth with which she is endowed bestows on her a role in Africa and the world which no one else can assume or fulfilled [2].

This enviable role placed on Nigeria has since been lost to the kind of leadership foisted on it. The leadership are engrossed in corruption, embezzlement and diversion of public funds into their personal coffers in and outside the country. The resultant effects are economic stagnation, widespread poverty, malnutrition and disease, destructive ethnic mobilisation and a wide range of social ills.

Nigeria's economic crisis can best be appreciated when viewed from the lenses of Africa's economic situation. In the view of Ayittey [3], Africa's deteriorating economic situation is baffling. The continent's untapped mineral wealth is immense and its tourism potential enormous. Yet, it is inexorably mired in steaming squalors, misery, deprivation and chaos. In his words:

Four out of 10 Africans live in absolute poverty and recent evidence suggests that poverty is on the increase. If Africa wants to reduce poverty by half over the next 15 years, it needs to attain and sustain an average annual growth rate of 7 percent - an enormous task [3].

Statistically, Ayittey observed that African continent consisting of 54 countries, is the least developed region of the Third World in 1997, the Purchasing Power Parities (PPP), GNP per capita for Africa was \$1,460, compared to \$1,590 for South Asia, $\$ 3,170$ for East Asia and $\$ 6,730$ for Latin America. Economic growth rated in Africa in the 1970s averaged 4 to 5\%, while Latin America records 6 and 7\% growth rate. From 1986 to 1993 the continent's real GNP per capital declined by $0.7 \%$, while the average for the third world increased by $2.7 \%$ for all Africa, real income per capital dropped by $14.6 \%$ from its level in 1965 , making most Africans worse off than they were at independence $[3,4]$.
He goes further to state that:

African growth rates in the late 1990s - around $5 \%$ on average were higher than the $2 \%$ growth rate of the early 1990s. But subtract an average population growth of $3 \%$ and that leaves miserly rates of growth of less than $2 \%$ in GNP per capita woefully insufficient to have a substantial impact on poverty [3].

Jackson and Jackson aver:

Around one in every five people on the earth lives in poverty. The poorest people are found in South Asia, Southeast Asia, and sub-Sahara Africa. With little or no purchasing power; many of them are destitute. Roughly 1billion humans are malnourished and 1.1 billion lack clean drinking water and proper health services. More than 15 million children a year die before reaching 6 years of age. These people have little hope of escaping poverty. Illiteracy is extremely high; and so is unemployment [5].

Democracy symbolizes the idea of ascending to power by the grace of the majority, which reflects elements of constitutionality and modelled in the pattern of the republics. Suffice it to say that the flow of power from the masses to the rulers justifies the theory and practices of the social contract in the modern days. Election, however, periodic is one of the cardinal and important elements of democracy. Liberal democracy stipulates that candidates are presented to the electorates and popularity is sacrosanct in the final selection. However, money plays important role in the electoral process. The importance of money cannot be underestimated in formation, organizing and registration of political parties, prosecution of election campaigns, and the proper conduct of elections which could range from internal to general elections. The choice made by the electorates will determine who eventually wins the election in democracy.

In the recent times in Nigeria, merchandisation of votes (vote-buying and vote-selling) has joined the political lexicon. It has joined the plethora of other electoral challenges and democracy in Nigeria. Political parties and politicians have come to terms that devotion of huge financial resources to the electorates will swing the electoral pendulum of victory in their favour, hence, political contest has become that of the highest bidder. Politicians and political practitioners, i.e. the government operators are taking the advantage of psychology of poverty (poverty and lack among the electorates, a situation of carrot and stick, povertyplenty syndrome) a situation whereby those in power 
and government taking advantage of the civil service status and the agrarian populace by owing the workers so many months of salary, emoluments pensions and gratuities and waiting towards the period of elections to pay them (one or two months) and then promise to pay them after the elections. One or two months of salary paid will make the workers and the populace to forget their months of anguish, hunger and poverty and begin to organize rallies and campaign to support the government that practically inclined their poverty.

On the other hand, politicians and political gladiators (especially) those who want to wring political power from the incumbent, in their own understanding devote also a huge amount of money to the electorates to seek votes from them.

Deductive from the above, the economic situation in Nigeria has greatly impacted on the sociopolitical and economic lives of the people. The citizens consider life first among the rest. You survive to live. Hence, it is a golden opportunity when they have something, anything they can use to bargain for a living and survival. Readily, become handy is their political power, franchise (the power to vote in an election). It is an axiomatic fact that it takes two to tangle. There cannot be merchandisation of votes i.e. without an unholy alliance between the politicians and the electorates. There must be someone who wants to sell and there must be someone who is ready to buy. There cannot be a seller without a buyer and vice versa.

This paper examines the political economic realities that contribute to the menace of electoral merchandisation in Ekiti 2018 election vis-à-vis Nigeria at large. Political economy approach (PEA) with its variance of rational choice theory is found handy/apt to examine the choices made by the electorates and the politicians in their quest for power [6].

However, the paper examines:

1. The importance of elections in democracy

2. Various challenges of elections in Nigeria

3. The menace of merchandisation of votes in Ekiti state and Nigeria as a whole

4. The political economic implication of the electoral merchandisation (vote-buying and vote-selling)

5. Alternative policy options are proffered to combat the menace of merchandisation of votes are provided in the work.

\section{CONCEPTUAL CLARIFICATIONS Merchandisation of Votes}

This simply means the menace of vote-buying and vote-selling or commodification of votes. An economic situation where by commodities are exchanged between two people, the buyer and the seller. In this political space, votes are the article of the commodities and merchandise. The politicians who are the buyers depend on the votes to cling onto power or wring power from the incumbent. YIAGA AFRICA Initiative, 2018 [6] described merchandisation of vote as a form of clientelism. Clientelism typically assume that political machines distribute rewards to persuade or mobilize the existing electorate. Clientelistic vote buying is therefore, "the proffering to voters of cash or (more commonly) minor consumption goods by political parties, in office or in opposition, in exchange for the recipient's vote" [7]. In many emerging democracies, voters themselves often demand gifts or hand-outs of some kind in return for their support. Studies from various scholars and thinkers on this issue give some insights on how to understand the phenomenon of vote - buying. Clientelist relationships involve two sets of actors: patrons that seek to maintain and build power and clients that seek protection, access to benefits and services, or insurance against risk [8]. Badalyan and Heinemann [9] described merchandisation of votes as political business cycles in their paper titled "Vote Buying or (Political) Business (Cycles) as Usual?" Vote buying to refer to two related strategies for winning elections. One strategy is to offer a monetary payment as a direct exchange of cash for votes. Another strategy is to buy turnout, that is, to offer cash payments to induce core supporters to cast their vote or to induce opposition voters to stay home. In addition to cash, parties often distribute a wide range of other material goods such as food, clothing, a bag of rice, as well as services such as medical care, transportation to the polling station etc. on the day of the election.

This opinion about merchandisation of votes has also been supported by many scholars. Baidoo, Dankwa and Eshun [10], opine that vote-buying is a transaction whereby candidates distribute private goods such as cash and gifts in exchange for electoral support or higher turnout. The focus here is for voters, especially party supporters and swing voters to turn out in their numbers and vote for the party. In this case, they see vote buying as the giving out of cash and other material items such as building materials, food and liquor for electorates especially party supporters to go out in their numbers and vote for the party. Effectively, electorates are paid solely to turn out and vote for the distributing party. The number of electorates who turn out to vote for a candidate is important in understanding people's political participation. This definition sees vote buying as a transaction (where there is a bargain and an agreement) or a trade. In the view of Schaffer and Schedler [11], the logic of trade demands that: (a) the actors involved (buyers and sellers) engage in effective exchange of money for goods or services. In the absence of mutual exchange, if buyers do not pay or sellers do not deliver, the act is not considered as trade but instances of fraud or robbery. To them, the logic of commercial transactions further demands that: (b) buyers and sellers understand what they are doing: that they enter a reciprocal relationship of exchange. In 
other words, if voters accept the money, but vote as they had planned to do anyway, they do not take part in an act of exchange. They are not selling their votes, but earning unilateral gains. In their view, voter turnout gives the election management body an idea about the image of the authority in the eyes of the electorate. It can give it cause to assess its election processes to eliminate steps that hinder turnout and improve its organization of elections with the introduction of other workable measures to lure eligible voters to the polling centres during elections. Again, Schaffer and Schedler [11] posit that if we embrace a literal understanding of the term anchored in the world of economic exchange, we may define the purchase of votes in the electoral arena as a market transaction in which parties, candidates, or intermediaries pay (in cash or kind) for "electoral services" delivered by individual citizens. They identify the electoral services to be either a favourable vote or a favourable abstention. They see vote buying as a market exchange and in their view; the commodity that changes hands in the acts of vote trading carries a well-defined institutional meaning. To them, in the vote buying transaction, electorates can be engaged to offer electoral services. These services may require supporters and swing voters to go out in their numbers and vote for the party while they are rewarded for the services. The services may also target opposition supporters by paying them to refrain from voting. To them, votes are formalized expressions of preference by individual members of decision-making bodies.

Baidoo et al., [10] opine that the history of vote buying is long in history. Indeed, vote buying which in some literature is referred to as clientelism has a long history. The use of electoral incentives to buy votes has been a frequent practice during electoral campaigns and elections in several developing and developed countries alike: the Roman Republic, Britain, the United States, Nicaragua, Argentina, Taiwan, and Lebanon, as well as African countries like Sao Tome and Principe, Nigeria, Kenya and Ghana. For example, Hicken, Leider, Ravanilla and Yang [12] account from their paper "Temptation in vote-selling: Evidence from a field experiment in the Philippines" that:

"Typically, each voter in a household will be offered a packet with their name on it, and campaigns track who accepted and who did not. Candidates may also engage in a second round of vote buying if they learn that a challenger is offering more money than they are. Campaigns seek to ensure that voters clearly associate the gift with their candidate. For example, the candidate's flyer may be stapled to packages of food handed out to voters or cash may be attached to flyer or letter from the candidate. Most commonly, candidates distribute money attached to a sample ballot, and encourage voters to take the ballots with them to the polls as a guide. The sample ballot includes not just the candidate's name, but also allied candidates from other races up and down the ticket."

Explaining this further, Baidoo et al., [10] submit that Vote buying appears in different forms in every society. It may take the form of direct payments to voters. To Schaffer and Schedler [11], vote buying in its literal sense, is a simple economic exchange. Candidates "buy" and citizens "sell" votes, as they buy and sell apples, shoes or television sets. He adds that the act of vote buying is a contract, or perhaps an auction, in which voters sell their votes to the highest bidder. Parties and candidates who offer material benefits to voters may generally aspire to purchase political support at the ballot box in accordance with the idea of market exchange. Other forms may include offering of employment before elections, giving out of gifts, provision of social infrastructure to communities on the "last minute" and conditional promises to individuals upon the election of a candidate. Political parties employ certain strategies to buy the votes of electorates. The strategies may focus on demobilizing active opponents or on mobilizing passive supporters. The former is often described as "negative" vote buying or "abstention buying", while the latter may be considered as "participation buying." These strategies may be intended to refrain electorates from casting their votes or ensure a high turnout but how the parties choose amongst the strategies when offering electoral incentives or buying votes remain a great question

\section{Elections and Democracy}

Election has become a buzz word in modern day governance. Given the attraction and acceptance of democratic system of government globally, it is no longer strange for authoritarian government to conduct elections in order to project the image of acceptance and popularity as witnessed in Hosni Mubarak's Egypt, Bashar Al Assad's Syria and other despotic regimes across Africa [13]. Election can simply be described as a situations whereby one is faced with the choice of two or more alternatives. Electorally, it can also be seen as a competitive process involving more than two or more persons, seeking to control both political and economic power with legitimate support of the electorate or those with the legitimate powers to elect representatives from among the contending persons. In this regards elections are means of selecting those to represent the people in different public positions within a polity. An election provides citizens with influence over policy making. Elections could be used for ratification of the existing government in power in the sense that they aim at giving the sitting government some appearances of popularity and mobilize the people for popular participation in development. But under liberal democracy, election plays wider role such as; 
instrument of accountability, mobilization of people, promotion of legitimacy, among other functions. Competitive political elections are vital to the survival of liberal vibrant of democracy. In the western democracies, elections are celebrations of fundamental human rights. These rights are expressed in political and civil rights. In general, political rights include the freedom of expression, freedom of association and assembly, the right to take part in the government of one's country and the right to vote and be voted for in at elections [14].

It should be noted that in the absences of some sort of elections there is no democracy. However certain conditions must be met for an election to qualify as a democratic one. These criteria are stated as follows:

(a) Ample chance for political parties to be formed by citizens and for them to put forward candidates for elections.

(b) The candidates so put forward must be allowed to freely run their campaigns within same set of roles.

(c) Registered voters must be given free access to vote freely for candidates (parties of their choice) without intimidation or retribution of any kind.

(d) Parties and candidates must be granted open and fair competition in order to avail the electorate of meaningful choices.

(e) The principle of universal suffrage should be upheld hence citizens who satisfy certain broad criteria such as age \& citizenship qualifications most have the right to vote.

(f) In conclusion each ballot box should be counted and reported honestly \& accurately [5].

Given the existence of the stated conditions coupled with regular interval of elections, citizens are then empowered to be able to remove and replace unpopular government. Hence governments are made to become more responsive to the people who form the basis/foundation of democracy

Elections carry out functions which are much more than just determine who forms the next government, they are conventionally viewed as a mechanism by which politicians are called upon to give account and forced to enact policies that somewhat reflect public opinion. This focuses on the bottom -up functions of elections i.e. political recruitment, representation, making of governments, policy influencing to mention but a few [13].

However a converse view held by the radicals [15] sees elections as a tool by which control is exercised by the government and political elites over their citizens (general population) making term malleable and more quiescent hence very governable. This view focuses on the top down functions of elections which includes legitimacy building, shaping of public opinions, and strengthening of the elites.

The third view is held by the realists who see elections as having no character whatsoever, that they are neither tools of public accountability nor a means of exercising political control [16]. Hence in reality elections can be objectively viewed as in two-way communication medium that provides the government and the governed (people), the elite and the masses with the opportunity to exert influence on each other.

Following from these realist view, elections are deemed to have the following stated functions but not limited to them:

1. Providing Representation: i.e. a means through which demands are directed from the populace /citizens to the government. And apart from the use of initiatives and recall, the electorate has no effective resources of ensuring that mandates are carried out, apart from the capacity to inflict punishment at the next elections.

2. Voter Education: this is done through the process of campaigns which inadvertently provides the electorate with substantial information about the various parties, polices, candidates, the political system and them current governments records to mention but a few. It should however be noted that voter education can take place if these information are provided and if the way they are provided engages pubic interest to stimulate debates as opposed to precipitating apathy and voter alienation. As a result of provision of distorted and incomplete information by political parties and candidates in their desperate bid to persuade rather than educate the electorate.

3. Influencing Policies: The ability of elections to serve as deterrence against radical and deeply unpopular governmental policies cannot be over emphasized. But others have agreed that government policy is more often than not shaped by practical contexts such as the state of the economy than by electoral considerations. However it's the view of the voters here that electoral considerations and other practical issues/ contexts such as the economy have a way of influencing policy either directly / indirectly.

4. Recruitment of politicians: Elections serve as the major/central source of political recruitment taking in cognizance the process through which candidates emerge from the various political patties. It should be noted that elections are typically unused to fill up positions that require specialist skills and knowledge such as doctors, engineers or nurses but that of talents related to 
electioneering which are possessed by politicians.

5. Building of legitimacy: Legitimacy is fostered through elections, providing justifications for a system of rule. This is the fundamental reason why even dictators pretend to hold elections (especially non- competitive ones) to mobilize the active consent of the citizens.

6. Lastly the manipulation and control of masses is easily done by the elites through elections. It's often used to neutralize political discontent and the opposition, by appearing to give the citizens power over the government but which in the real sense is that the regimes remain but governments come and go.

Although the importance of elections cannot be over-emphasized as they provide the citizens with the means to determine those who will hold the reins of government. Hence it can be said that results are the most important factor in elections (winners / losers). However the interpretation of result remains stochastic because it's noted that several factors influence the interest of the citizens (public interest) in the voting process. However a simple means of understanding election result is embedded in knowing why voters vote the way they do. What influencing the pattern and behaviour of the citizens in the voting process, why do then vote in a particular way?

Democratic elections are not without their challenges especially in authoritarian states when they conduct elections, through the manipulation of outcomes by corrupting the criteria essential for free and fair electoral processes.

Some of these acts of corruption include:

(a) Conduct of irregular registration procedures aimed at depriving individuals/groups of their right to vote.

(b) Or the establishing of restrictive criteria for registration, thus disenfranchising otherwise qualified voters.

(c) Tampering with voting registers or simply mislaying them.

(d) Bribing, and or threatening of voters with physical harm for/for not voting in predetermined patterns.

(e) Rigging, stuffing of ballot boxes, or missing ballots boxes.

(f) Insufficient or closed polling booths/voting material in pre-selected areas.

(g) And finally the corrupt tallying and counting of ballot boxes [13].

These are some of the ways in which the electoral process can be tainted and made to be devoid of any semblance of democracy. It should also be noted that although these acts are a feature of authoritarian regimes but they are not limited to them but extends also to established democratic regimes. Jackson and Jackson [5] gave ingenious examples of vote purchase to include charity circumcision ceremonies in 1991 Turkish elections and the 2002 Colombian Viagra for votes trading.

\section{THEORETICAL FOUNDATION Political Economy Approach}

As observed by Harris [17] any genuine understanding of the problem of development in Africa requires an analytical perspective that goes beyond boundaries of Western social sciences particularly those boundaries that divide the studying of economics and science. On a broad form, Harris submits that the Political Economy Approach would provide a better understanding of national issues since it situates them within a conceptually global perspectives. A good understanding of the Political Economic Approach is stated in the 'Preface to Manifesto of the Communist Party'. In this treatise, Karl Marx posits that:

In the social production of life, men enter into definite relations that are indispensable and independent of their will; these relations of production correspond to definite stage of development of their material forces of production. The sub-total of these relations of production constitutes the economic structure of society - the real foundation, on which rises a legal and political superstructure and to which correspond definite forms of social consciousness. The mode of production of material life determines the social, political and intellectual life process in general. It is not the consciousness of men that determines their being, but, on the contrary, their social being that determines their consciousness [18].

Corroborating this position, Mimiko [19] defined it as 'testament on the supremacy of economic issues'. He contends that economic issues constitute the foundation of society. It is in the process of producing the material needs of existences of man, that man's attitude, behaviour, culture, etc. are formed. Politics, religions, arts, ideology, etc. cannot have a place unless following the economic variables. They are nothing but different manifestations of economic reality. On this structure (economics) all other superstructure - politics, religion, ideology etc. are built. In other words, the material needs of man takes precedence over, his consciousness. Marx demonstrated clearly that the interplay between the infrastructure and the superstructure produces a complicated arrangement of society into mainly two social classes on the basis of 
their ownership or non-ownership of means of (economic) production $[20,21]$.

Rational Choice Theory can be seen to be based on the concept of rational action, taken from neoclassical economic theory [22]. Rational action as used in economics implies the maximization of well-defined objectives or goals (e.g. profit, wealth, or utility). It is important to note that Rational Choice Theory posits that maximizing behaviours is not restricted to economic agents (e.g consumers and business firms) but applies to all participants in both political and economic markets. Thus, 'families, social movements, political parties and officials, governments, racial and ethnic groups, churches or scientists are assumed to optimize their utility functions' [23]. In other words, according to Rational Choice Theory, maximizing behaviour is universal, applying to actors in both economic, as well as political market [24].

The theory of rational choice can offer guidelines for studying economic and social behaviour. By providing a well-defined objective to be pursued, rational choice theory can help elucidate how individuals should behave [23]. Accordingly, the objective function of, for example, wealth, is then said to define rationality. Viewing rationality as utility maximization implies that actors or market participants attempts to reach a point where "their optimally chosen actions generate best outcomes" [23]. Since it is assumed that the primary interest of the individual's action is his personal welfare, rational choice postulates actors to be self-interested that is, actors engage in selfregarding behaviours. Rational Choice Theory is "based upon the concept that individuals are rational egoists". The principle of utilitarian action is considered "The hallmark of Rational Choice Theory is the sense that all social behaviour is seen as explicable by what is called a generalised calculus of utility - maximizing behaviours" [23].

In political markets, rational choice theorists would argue that politicians seek power in order to use it to maximize their individual interests [22]. Individuals within the given set of constraints (i.e. market in incentive structures) made possible by the society's institutional arrangements, to maximize welldefined objective functions. The theory of rational choice then "is grounded on the neo-classical economic model of rationality with its basis in the concept of utility function positing that social action is guided by the goal of maximizing or (satisfying with respect to) utility" [23].

Rational Choice Theory, as it applies is based on four presuppositions. According to Mbaku [24]:

1. In his relations to other members of society, the individual seeks to maximize his self-interest - that is, the individual engages in optimizing behaviour;
2. that, the choices made earlier can impact and alter the alternatives available to individuals in subsequent periods;

3. Individuals, through socialization, come to recognize their dependence on other members of society. As a consequence, individuals may, from time to time forego some of their 'selfish' interests in order to promote 'group' goals. Group identification - for example with an ethnic group - can be seen as part of the tradition passed down from one generation to another;

4. Finally, to maximise their objectives, individuals may form or join group that allow them to engage in collective decision making. It must be understood that individuals may have many goals to pursue and as such, may join more than one group.

All the basic assumptions are related to merchandisation of votes in Nigeria. It is when your basic economic needs which serve as superstructure are met that one can now be talking about substructures of politics and religion. The people/citizens among others seek to maximize economic gains and political gladiators tend to optimize their political choices, thereby, the two deciding to merchandise their voting powers.

\section{MERCHANDISATION OF VOTES AND THE 2018 EKITI STATE OF NIGERIA GUBERNATORIAL ELECTIONS \\ Background to the 2018 gubernatorial elections in Ekiti state}

Elections and voting are important mechanisms for selecting leaders for political offices in every democracy. As a critical component of the electoral process, political parties have a strong influence on the quality, salience, and credibility of the political process. They also help to inform the voters since their expected ideological differentiation should help the electorate in charting preferred lines of policy preferences that ultimately lead to a clearer system of rational choice making among competing parties and programmes YIAGA AFRICA Initiative, 2018 [6]. Ekiti, like most states in the southwestern part of Nigeria, has been a two-party state. Since the creation of the state in 1996 and commencement of party politics in the third republic, political leaderships across the executive and legislative arms have oscillated between two major parties, divided along rather artificial and titular extremes of left and right; so-labelled for fleeting partisan conveniences rather than genuine or observable ideological rivets. For the 2018 governorship election in Ekiti state, the two parties are the All Progressives Congress (APC), which won the 14 July election, and the People's Democratic Party (PDP), both parties claiming majority of votes cast. Other parties including 
AD, LP, PPA, PPA, YDP, ADP, APDA, KOWA, GPN, NPC, PANDEL, PPA, PDC, MPN and others, could not secure more than 2 per cent of the total number of votes cast The overriding drive of/motivation for membership of all parties, irrespective of names, remains selfinterest. Deep ideological hardliners and genuine moderates are apparently nonexistent on Nigeria's political scene for now (YIAGA AFRICA Initiative, 2018) [6]. So far as overt considerations of politicians are adjudged, and Ekiti cannot be an exception, personal interest is the endemic driving force. Not particularly expansive in terms of private commercial ventures, Ekiti becomes agog soon as it is time for elections. An average indigene of Ekiti state becomes politically active during elections because of the opportunity it provides for distributive politics. They demonstrate sufficient interest in who becomes the governor, state assembly representatives, even local government chairpersons and their counsellors. The 2018 governorship election was no exception as the entire electorates, lettered and unlettered, old and young, remained awake from the period of campaigns through voting. Campaign fields in the state have never been scanty, even as songs and dancers often do come in copious, involuntary harvests, at such occasions when rival parties reach out on mutual self-annihilation missions, even as contents of speeches reek bile and venom against occupiers of targeted seats. Factually, some of the attendants at campaigns might have been encouraged by cash but majority of those who make it often to campaign grounds have personal convictions of the necessity of doing so, a trait which tells in their candor and comportment, and general demeanor during campaigns. Irrespective of patronage politics, an average Ekiti electorate remains deeply connected and informed about political developments within and about his/her environment. The figure of 405,861 accredited as voters in the 2018 gubernatorial election exercise is a validation of high political maturity of an average Ekiti person, given the entire population of the state which remains 2.3 million, according to the 2006 census (YIAGA AFRICA Initiative, 2018) [6]. Notwithstanding, the state has experienced scores of politically motivated violence, arson, often culminating in killings, maiming, kidnaps, and sundry other untoward developments.

\section{Presentation and analysis of data}

Merchandisation of vote vis-à-vis vote-buying and vote selling in this magnitude is new in Nigeria political space. It became noticeable in the 2018 gubernatorial elections and pose a serious challenge to the Nigerian democratic process.

The field study conducted in 2019 indicate a massive merchandisation of votes in Ekiti in 2018. In the conduct of the research, 300 questionnaires were evenly distributed in the three Senatorial district of the state Ekiti North (Ido-Ekiti), Ekiti South (Ikere Ekiti) and Ekiti Central (Ado Ekiti) were purposively selected for the research. Despite all efforts geared toward the research, 297 questionnaires were retrieved. The presentation and analysis are as follows:

Research Question 1: What is the nature of vote buying in Nigeria?

Table-1: Frequency, Mean ranking and Chi Square showing Nature of Vote Buying

\begin{tabular}{|c|c|c|c|c|c|c|c|c|}
\hline \multirow{2}{*}{ Items } & \multicolumn{7}{|c|}{ Response } & \multirow{2}{*}{$\begin{array}{l}\text { Mean } \\
\text { Rank }\end{array}$} \\
\hline & & SA & $\mathbf{A}$ & UN & D & SD & Total & \\
\hline \multirow{2}{*}{$\begin{array}{l}\text { In my area, politicians and or political parties give money } \\
\text { to voters before election }\end{array}$} & $\mathrm{F}$ & \begin{tabular}{|l|}
156 \\
\end{tabular} & 62 & 27 & 17 & 35 & 297 & 7.88 \\
\hline & $\%$ & 52.5 & 20.9 & 9.1 & 5.7 & 11.8 & 100.0 & \\
\hline \multirow{2}{*}{$\begin{array}{l}\text { In my area, politicians and or political parties give money } \\
\text { to voters during elections }\end{array}$} & $\mathrm{F}$ & 154 & 79 & 24 & 26 & 14 & 297 & 8.24 \\
\hline & $\%$ & $\begin{array}{l}51.9 \\
\end{array}$ & 26.6 & 8.1 & 8.8 & 4.7 & 100.0 & \\
\hline \multirow{2}{*}{$\begin{array}{l}\text { In my area, politicians and or political parties give } \\
\text { materials (food, clothes and appointments) to voters in } \\
\text { order to win elections }\end{array}$} & $\mathrm{F}$ & 161 & 70 & 36 & 12 & 18 & 297 & 8.49 \\
\hline & $\%$ & 54.2 & 23.6 & 12.1 & 4.0 & 6.1 & 100.0 & \\
\hline \multirow{2}{*}{$\begin{array}{l}\text { In my area, politicians and or political parties give } \\
\text { materials (food, clothes and appointments) to local } \\
\text { political elites in order to win elections }\end{array}$} & $\mathrm{F}$ & 138 & 85 & 31 & 13 & 30 & 297 & 7.88 \\
\hline & $\%$ & 46.5 & 28.6 & 10.4 & 4.4 & 10.1 & 100.0 & \\
\hline \multirow{2}{*}{$\begin{array}{l}\text { In my area, politicians and or political parties give money } \\
\text { to political elites during elections }\end{array}$} & $\mathrm{F}$ & 142 & 79 & 36 & 21 & 19 & 297 & 7.93 \\
\hline & $\%$ & 47.8 & 26.6 & 12.1 & 7.1 & 6.4 & 100.0 & \\
\hline \multirow{2}{*}{$\begin{array}{l}\text { In my area, politicians and or political parties give } \\
\text { materials (food, clothes) to Wards/ constituency in order } \\
\text { to win elections }\end{array}$} & $\mathrm{F}$ & 144 & 86 & 31 & 17 & 19 & 297 & 8.03 \\
\hline & $\%$ & 48.5 & 29.0 & 10.4 & 5.7 & 6.4 & 100.0 & \\
\hline \multirow{2}{*}{$\begin{array}{l}\text { In my area, politicians and or political parties purchase } \\
\text { cars, motorbikes, houses to give to people in order to win } \\
\text { elections }\end{array}$} & $\mathrm{F}$ & 73 & 59 & 64 & 43 & 58 & 297 & 5.64 \\
\hline & $\%$ & 24.6 & 19.9 & 21.5 & 14.5 & 19.5 & 100.0 & \\
\hline \multirow{2}{*}{$\begin{array}{l}\text { In my area, politicians and or political parties pay thugs to } \\
\text { intimidate and harass electorates during elections }\end{array}$} & $\mathrm{F}$ & 82 & 85 & 63 & 27 & 40 & 297 & 6.39 \\
\hline & $\%$ & 27.6 & 28.6 & $21 . .2$ & 9.1 & 13.5 & 100.0 & \\
\hline \multirow{2}{*}{$\begin{array}{l}\text { In my area, politicians and or political parties pay thugs to } \\
\text { snatch ballot boxes during elections }\end{array}$} & $\mathrm{F}$ & 88 & 71 & 66 & 25 & 47 & 297 & 6.31 \\
\hline & $\%$ & 29.6 & 23.9 & 22.2 & 8.4 & 15.8 & 100.0 & \\
\hline
\end{tabular}




\begin{tabular}{|c|c|c|c|c|c|c|c|c|}
\hline \multirow{2}{*}{$\begin{array}{l}\text { In my area, politicians and or political parties pay security } \\
\text { agents to aid electoral fraud }\end{array}$} & $\mathrm{F}$ & 75 & 63 & 90 & 30 & 39 & 297 & 5.94 \\
\hline & $\%$ & 25.3 & 21.2 & 30.3 & 10.1 & 13.1 & 100.0 & \\
\hline \multirow{2}{*}{$\begin{array}{l}\text { In my area, politicians and or political parties pay electoral } \\
\text { officials to aid electoral fraud }\end{array}$} & $\mathrm{F}$ & 66 & 67 & 101 & 35 & 28 & 297 & 5.84 \\
\hline & $\%$ & 22.2 & 22.6 & 34.0 & 11.8 & 9.4 & 100.0 & \\
\hline \multirow{2}{*}{$\begin{array}{l}\text { In my area, politicians and or political parties give money } \\
\text { to delegates to buy votes during party primaries }\end{array}$} & $\mathrm{F}$ & 107 & 64 & 71 & 34 & 21 & 297 & 6.72 \\
\hline & $\%$ & 36.0 & 21.5 & 23.9 & 11.4 & 7.1 & 100.0 & \\
\hline \multirow{2}{*}{$\begin{array}{l}\text { In my area, politicians and or political parties pay salary } \\
\text { arrears during elections to buy votes during elections }\end{array}$} & $\mathrm{F}$ & 71 & 55 & 67 & 41 & 63 & 297 & 5.70 \\
\hline & $\%$ & 23.9 & 18.5 & 22.6 & 13.8 & 21.2 & 100.0 & \\
\hline \multirow[t]{2}{*}{ Averaged Total } & $\mathrm{F}$ & 112 & 72 & 54 & 26 & 33 & 297 & \\
\hline & $\%$ & 37.7 & 24.2 & 18.2 & 8.8 & 11.1 & 100.0 & \\
\hline \multirow[t]{3}{*}{ Friedman Chi Square Test } & $\mathrm{X}^{2}$ & & \multicolumn{5}{|c|}{428.480} & \\
\hline & $\mathrm{df}$ & & \multicolumn{5}{|l|}{12} & \\
\hline & $\mathrm{p}$ & & \multicolumn{5}{|c|}{$<.05$} & \\
\hline
\end{tabular}

Source: Researcher's Field work 2019

The findings on the statements relating to the nature of vote buying were summarized in Table-1. Mean distributions were used to rank the various nature of vote buying identified and the $X^{2}$ value of 428.480 , df of 12 and a $p$ value that was less than 0.05 level of significant proved that the items significantly vary in ranking and this explain the relevance of each statement. Based on highest ranking, the statements would be explained. With a mean value of 8.49 , it was noted that most of the respondents $(77.8 \%)$ were in support of the statement that said politicians and or political parties give materials (food, clothes and appointments) to voters in order to win elections in their areas, $12.1 \%$ were not certain, while $10.1 \%$ negated the view. This means that the most recognized and practiced nature of vote buying is that done via materials such as food, clothes and appointments to voters in order to win election. Ranked next to this $(\mathrm{M}=8.24)$ is giving of money to voters during election and this was such that $78.5 \%$ of the respondents supported the statement that politicians and or political parties give money to voters during elections in their area, $8.1 \%$ were indecisive, while $13.5 \%$ did not agree. Next to this in ranking (8.03) was the provision of materials to wards and constituency. This was such that $77.5 \%$ supported the statement that politicians and or political parties give materials (food, clothes) to Wards or constituency in order to win elections, $10.4 \%$ were indifferent in response, while $12.1 \%$ negated it. With a mean score of 7.93, majority of the respondents (74.4\%) affirmed the statement that politicians and or political parties give money to political elites during elections, $12.1 \%$ were indifferent, while $13.5 \%$ negated the idea. On a tie mean score $(\mathrm{M}=7.88)$, it was further indicated that politicians and or political parties give materials (food, clothes and appointments) to local political elites in order to win elections. This was with $75.1 \%$ affirmation, $10.4 \%$ uncertain response and just $14.5 \%$ negation. Also, majority (73.4\%) supported the statement that said politicians and or political parties give money to voters before election ( $M=7.88), 9.1 \%$ were indifferent, while $17.5 \%$ negated the view.
On the ranking scale, majority $57.5 \%$ of the respondents supported the statement that said politicians and or political parties give money to delegates to buy votes during party primaries $(M=6.72), 23.9 \%$ felt indifferent, while $18.5 \%$ negated it. Majority of the respondents supported the view that politicians and or political parties pay thugs to intimidate and harass electorates during elections. This was ranked with mean score of 6.39 and $56.2 \%$ affirmed it. Rated next to this was the payment of thugs to snatch ballot boxes during elections by politicians and or political parties $(\mathrm{M}=6.31)$ and this was with $53.5 \%$. With a mean of 5.94 , it was observed that $46.5 \%$ affirmed that politicians and or political parties pay security agents to aid electoral fraud during election, $30.3 \%$ were indecisive, while $23.2 \%$ negated it. At a close range ( $\mathrm{M}=5.84)$, majority (44.8\%) of the respondents supported the statement that said politicians and or political parties electoral officials to aid electoral fraud during elections. The payment of salary arrears during elections to buy votes during elections was rated before the least with a mean score of 5.70 and the findings was such that $42.4 \%$ supported the statement, $22.6 \%$ felt indifferent, while $35 \%$ negated it.

Lastly with a mean score of 5.64, least ranked form of vote buying was the purchase cars, motorbikes, houses to give to people in order to win elections. The extent of agreement was such that $44.5 \%$ of the respondents affirmed the statement, $21.5 \%$ were indifferent, while $34 \%$ negated it.

The average summary revealed that $37.7 \%$ of the respondents strongly agreed with the identified nature of vote buying, $24.2 \%$ agreed, $18.2 \%$ were indecisive, $8.8 \%$ disagreed, while $11.1 \%$ strongly disagreed. Conclusively, it means that most of the respondents $(61.9 \%)$ confirmed the forms through which vote buying occurs.

Research Question 2: Who are the vote buyers in Nigeria? 
Table-2: Frequency, Mean ranking and Chi Square showing Nature of Vote Buying

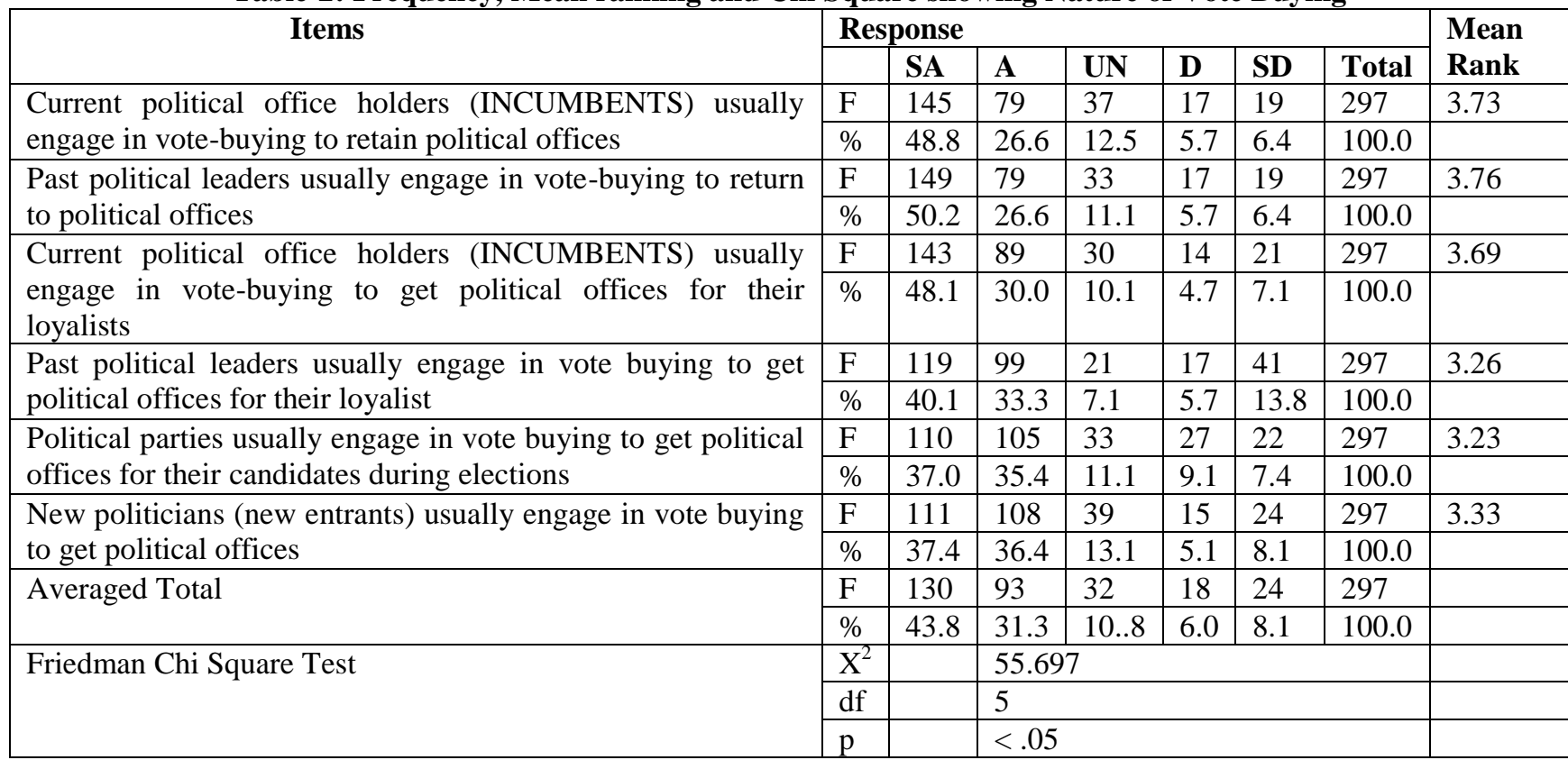

Source: Researcher's Field work 2019

The analysis on the type of vote buyers in Nigeria indicated that majority of the respondents (75.4\%) supported the statement that current political office holders (Incumbents) usually engage in votebuying to retain political offices, $12.5 \%$ were not certain with their response, while $12.1 \%$ negated it. It was also supported by most of the respondents (76.8\%) that past political leaders usually engage in vote-buying to return to political offices, $11.1 \%$ were indecisive, while $12.1 \%$ felt otherwise. Majority of the respondents (78.1\%) affirmed the statement that said current political office holders (Incumbents) usually engage in vote-buying to get political offices for their loyalists, $10.1 \%$ felt indifferent, while $11.8 \%$ did not agree. In a similar trend, most of the sampled respondents $(73.4 \%)$ of the respondents affirmed the statement that past political leaders usually engage in vote buying to get political offices for their loyalist, $7.1 \%$ were indifferent, while $19.5 \%$ felt otherwise.

Further observations revealed that $72.4 \%$ of the respondents supported the statement that political parties usually engage in vote buying to get political offices for their candidates during elections, $11.1 \%$ were indifferent in response, while $16.5 \%$ negated the view. Lastly, it was observed that $73.8 \%$ of the respondents supported the statement that new politicians (new entrants) usually engage in vote buying to get political offices, $13.1 \%$ were indecisive, while $13.2 \%$ negated the statement. These shows that the various mentions categories of people engage in vote buying. The average summary indicated that $75.1 \%$ of the sample confirmed the buying of votes by the various identified categories of people. For further understanding of those that mostly involved in this act, mean ranking was adopted and the chi square result revealed that the $X^{2}$ value of 55.697 , df of 5 had a $p$ value that was less than 0.05 level of significant. These implied that the observed mean distributions were valid for conclusion. Based on the mean ranking, the highest rated vote buyers were past political leaders who do so to return to political offices $(M=3.76)$. This was followed by current political office holders (Incumbents) and they do so to retain political offices $(M=3.73)$. Again, the current political office holders (Incumbents) were rated next $(\mathrm{M}=3.69)$ with the purpose of getting political offices for their loyalists. The ranking revealed that new politicians (new entrants) $(\mathrm{M}=3.33)$ with the purpose of getting political offices were next, while past political leaders $(M=3.26)$ with the intent of getting political offices for their loyalist came after it. The least ranked political parties who buy vote $(M=3.23)$ with the aims of getting political offices for their candidates during elections.

Conclusively, the prominent vote buyers are past political leaders who do so to return to political offices, while the least were political parties who buy vote with the aims of getting political offices for their candidates during elections.

Research Question 3: What are the reasons for vote buying and selling in Nigeria? 
Table-3: Frequency, Mean ranking and Chi Square showing the reasons for vote buying and selling in Nigeria

\begin{tabular}{|c|c|c|c|c|c|c|c|c|}
\hline \multirow[t]{2}{*}{ Items } & \multicolumn{7}{|c|}{ Response } & \multirow{2}{*}{$\begin{array}{l}\text { Mean } \\
\text { Rank }\end{array}$} \\
\hline & & SA & $\mathbf{A}$ & UN & D & SD & Total & \\
\hline \multirow{2}{*}{$\begin{array}{l}\text { People sell their votes because they see the money } \\
\text { or materials as their share of the national cake }\end{array}$} & $\mathrm{F}$ & 126 & 67 & 52 & 17 & 35 & 297 & 7.62 \\
\hline & $\%$ & 42.4 & 22.6 & 17.5 & 5.7 & 11.8 & 100.0 & \\
\hline \multirow{2}{*}{$\begin{array}{l}\text { Money derived from vote buying is used to provide } \\
\text { for the needs of family members }\end{array}$} & $\mathrm{F}$ & 115 & 66 & 50 & 20 & 46 & 297 & 7.31 \\
\hline & $\%$ & 38.7 & 22.2 & 16.8 & 6.7 & 15.5 & 100.0 & \\
\hline \multirow[t]{2}{*}{ People sell their votes due to high level of illiteracy } & $\mathrm{F}$ & 70 & 68 & 52 & 31 & 76 & 297 & 6.47 \\
\hline & $\%$ & 23.6 & 22.9 & 17.5 & 10.4 & 25.6 & 100.0 & \\
\hline \multirow{2}{*}{$\begin{array}{l}\text { People sell their votes because the manifestoes of } \\
\text { the various parties are unclear }\end{array}$} & $\mathrm{F}$ & 66 & 62 & 50 & 36 & 83 & 297 & 6.12 \\
\hline & $\%$ & 22.2 & 20.9 & 16.8 & 12.1 & 27.9 & 100.0 & \\
\hline \multirow{2}{*}{$\begin{array}{l}\text { People sell their votes because there is no law that } \\
\text { prohibits vote selling and buying }\end{array}$} & $\mathrm{F}$ & 95 & 45 & 33 & 23 & 101 & 297 & 6.30 \\
\hline & $\%$ & 32.0 & 15.2 & 11.1 & 7.7 & 34.0 & 100.0 & \\
\hline \multirow{2}{*}{$\begin{array}{l}\text { People buy or sells votes because there is no } \\
\text { punishment for vote selling and buying }\end{array}$} & $\mathrm{F}$ & 79 & 56 & 20 & 38 & 104 & 297 & 6.01 \\
\hline & $\%$ & 26.6 & 18.9 & 6.7 & 12.8 & 35.0 & 100.0 & \\
\hline \multirow{2}{*}{$\begin{array}{l}\text { It is believed that those who can afford to buy votes } \\
\text { would do well in political offices }\end{array}$} & $\mathrm{F}$ & 53 & 82 & 42 & 51 & 69 & 297 & 5.80 \\
\hline & $\%$ & 17.8 & 27.6 & 14.1 & 17.2 & 23.2 & 100.0 & \\
\hline \multirow{2}{*}{$\begin{array}{l}\text { Politicians offer money for votes because they see } \\
\text { political offices as business investment }\end{array}$} & $\mathrm{F}$ & 114 & 92 & 35 & 26 & 30 & 297 & 7.94 \\
\hline & $\%$ & 38.4 & 31.0 & 11.8 & 8.8 & 10.1 & 100.0 & \\
\hline \multirow[t]{2}{*}{ Vote buying is a better means of influencing votes } & $\mathrm{F}$ & 120 & 70 & 47 & 26 & 34 & 297 & 7.52 \\
\hline & $\%$ & 40.4 & 23.6 & 15.8 & 8.8 & 11.4 & 100.0 & \\
\hline \multirow{2}{*}{$\begin{array}{l}\text { Politicians or parties that do not buy votes cannot } \\
\text { win elections }\end{array}$} & $\mathrm{F}$ & 99 & 76 & 54 & 36 & 32 & 297 & 6.92 \\
\hline & $\%$ & 33.3 & 25.6 & 18.2 & 12.1 & 10.8 & 100.0 & \\
\hline \multirow{2}{*}{$\begin{array}{l}\text { Electorates sell their votes because they believe } \\
\text { their votes don't count }\end{array}$} & $\mathrm{F}$ & 111 & 75 & 51 & 32 & 28 & 297 & 7.44 \\
\hline & $\%$ & 37.4 & 25.3 & 17.2 & 10.8 & 9.4 & 100.0 & \\
\hline \multirow[t]{2}{*}{ Politicians buy votes as investment against failure } & $\mathrm{F}$ & 121 & 92 & 34 & 19 & 31 & 297 & 7.95 \\
\hline & $\%$ & 40.7 & 31.0 & 11.4 & 6.4 & 10.4 & 100.0 & \\
\hline \multirow[t]{2}{*}{ Those who buy votes usually win elections } & $\mathrm{F}$ & 106 & 103 & 43 & 16 & 29 & 297 & 7.60 \\
\hline & $\%$ & 35.7 & 34.7 & 14.5 & 5.4 & 9.8 & 100.0 & \\
\hline \multirow[t]{2}{*}{ Averaged Total } & $\mathrm{F}$ & 98 & 73 & 43 & 29 & 54 & 297 & \\
\hline & $\%$ & 33.0 & 24.6 & 14.5 & 9.8 & 18.2 & 100.0 & \\
\hline \multirow[t]{3}{*}{ Friedman Chi Square Test } & $\mathrm{X}^{2}$ & & \multicolumn{5}{|c|}{192.634} & \\
\hline & $\mathrm{df}$ & & \multicolumn{5}{|l|}{12} & \\
\hline & $\mathrm{p}$ & & \multicolumn{5}{|l|}{$<.05$} & \\
\hline
\end{tabular}

Source: Researcher's Field work 2019

Table-3 shows the responses made on statements explaining reasons for vote buying and selling. The identified factors were rated based on the mean distributions. The chi square value indicated an observed $X^{2}$ value of 192.634 ,df of 12 and a $p$ value that was less than 0.05 level of significant. This implied that the mean ranking was valid for explanation.

Based on the ranking, it was noted that majority of the respondents $(71.7 \%)$ affirmed the statement that politicians buy vote as investment against failure $(\mathrm{M}=7.95)$. Rated next to this was the majority $(69.4 \%)$ affirmation that politicians offer money for votes because they see political offices as business investment $(\mathrm{M}=7.94)$. In a similar trend with mean score of 7.62, it was noted that majority of the respondents $(65 \%)$ supported the statement that people sell their votes because they see the money or materials as their share of the national cake. With a mean of 7.60, it was indicated that majority of the respondents (70.4\%) supported the statement that those who buy votes usually win elections. Rated next is the majority $(64 \%)$ support that vote buying is a better means of influencing votes $(\mathrm{M}=7.52)$. It was also indicated that with a mean score of 7.44 , it was indicated that $62.7 \%$ of the respondents affirmed the statement that said electorates sell their votes because they believe their vote don't count. The ranking indicated that the next reason for vote buying was for providing for the needs of family members $(\mathrm{M}=7.31)$. This was such that $60.9 \%$ affirmed the statement, $16.8 \%$ felt indifferent, while $22.2 \%$ negated it. The mean score of 6.92 ranked the statement that politicians or parties that do not buy votes cannot win elections. This was such that $58.9 \%$ affirmed it. The mean score of 6.47 rated the statement that people sell their votes due to high level of illiteracy and $46.5 \%$ supported the statement. With the mean of 6.30 , the statement that people sell their votes because there is no law that prohibits vote selling and buying was supported by $47.2 \%$ of the respondents.

It was indicated that $43.1 \%$ of the respondents supported the statement that people sell their votes because the manifestoes of the various parties are unclear, $16.8 \%$ felt indifferent, while $40 \%$ negated it and it was rated based on the mean score of 6.12. Also, 
$45.5 \%$ of the respondents supported the statement that said people buy or sells votes because there is no punishment for vote selling and buying, $14.1 \%$ were indifferent, while $40.4 \%$ negated it, but it was rated with a mean score of 6.01. Lastly rated was the statement that said it is believed that those who can afford to buy votes would do well in political offices and this was such that $45.4 \%$ affirmed it, $14.1 \%$ were uncertain in response, while $40.4 \%$ disagreed. This means that doing well is not a reason or assurance attached to vote buying.

Research Question 4: Who are the sets of contestants involved in vote buying?

Table-4: Frequency, Mean ranking and Chi Square showing the sets of contestants involved in vote buying

\begin{tabular}{|c|c|c|c|c|c|c|c|c|}
\hline \multirow[t]{2}{*}{ Items } & \multicolumn{7}{|c|}{ Response } & \multirow{2}{*}{$\begin{array}{l}\text { Mean } \\
\text { Rank }\end{array}$} \\
\hline & & SA & $\mathbf{A}$ & UN & D & SD & Total & \\
\hline \multirow{2}{*}{$\begin{array}{l}\text { Presidential contestants and or supporters are the usual } \\
\text { vote buyers }\end{array}$} & $\mathrm{F}$ & 119 & 90 & 33 & 28 & 27 & 297 & 5.04 \\
\hline & $\%$ & 40.1 & 30.3 & 11.1 & 9.4 & 9.1 & 100.0 & \\
\hline \multirow{2}{*}{$\begin{array}{l}\text { Gubernatorial (Governorship) contestants and or } \\
\text { supporters are the usual vote buyers }\end{array}$} & $\mathrm{F}$ & 124 & 87 & 43 & 26 & 17 & 297 & 5.13 \\
\hline & $\%$ & 41.8 & 29.3 & 14.5 & 8.8 & 5.7 & 100.0 & \\
\hline \multirow{2}{*}{$\begin{array}{l}\text { House of assembly contestants or supporters are the } \\
\text { usual vote buyers }\end{array}$} & $\mathrm{F}$ & 87 & 96 & 60 & 27 & 27 & 297 & 4.41 \\
\hline & $\%$ & 29.3 & 32.3 & 20.2 & 9.1 & 9.1 & 100.0 & \\
\hline \multirow{2}{*}{$\begin{array}{l}\text { Senate contestants or supporters are the usual vote } \\
\text { buyers }\end{array}$} & $\mathrm{F}$ & 78 & 104 & 57 & 29 & 29 & 297 & 4.29 \\
\hline & $\%$ & 26.3 & 35.0 & 19.2 & 9.8 & 9.8 & 100.0 & \\
\hline \multirow{2}{*}{$\begin{array}{l}\text { House of representatives' contestants or supporters are } \\
\text { the usual vote buyers }\end{array}$} & $\mathrm{F}$ & 75 & 119 & 50 & 20 & 33 & 297 & 4.29 \\
\hline & $\%$ & 25.3 & 40.1 & 16.8 & 6.7 & 11.1 & 100.0 & \\
\hline \multirow{2}{*}{$\begin{array}{llll}\text { Local Government } & \text { Chairmanship } & \text { contestants } & \text { or } \\
\text { supporters are the usual vote buyers } & & \end{array}$} & $\mathrm{F}$ & 68 & 118 & 54 & 30 & 27 & 297 & 4.22 \\
\hline & $\%$ & 22.9 & 39.7 & 18.2 & 10.1 & 9.1 & 100.0 & \\
\hline \multirow{2}{*}{$\begin{array}{l}\text { Local Government councillorships contestants } \\
\text { supporters are the usual vote buyers }\end{array}$} & $\mathrm{F}$ & 78 & 117 & 49 & 25 & 28 & 297 & 4.38 \\
\hline & $\%$ & 26.3 & 39.4 & 16.5 & 8.4 & 8.4 & 100.0 & \\
\hline \multirow{2}{*}{$\begin{array}{l}\text { Contestants and or supporters during primary election } \\
\text { (internal party elections) are the usual vote buyers }\end{array}$} & $\mathrm{F}$ & 85 & 94 & 44 & 27 & 47 & 297 & 4.24 \\
\hline & $\%$ & 28.6 & 31.6 & 14.8 & 9.1 & 15.8 & 100.0 & \\
\hline \multirow[t]{2}{*}{ Averaged Total } & $\mathrm{F}$ & 89 & 103 & 49 & 27 & 29 & 297 & \\
\hline & $\%$ & 30.0 & 34.7 & 16.5 & 9.1 & 9.8 & 100.0 & \\
\hline \multirow[t]{3}{*}{ Friedman Chi Square Test } & $\mathrm{X}^{2}$ & & \multicolumn{5}{|c|}{95.325} & \\
\hline & $\mathrm{df}$ & & \multicolumn{5}{|l|}{7} & \\
\hline & $\mathrm{p}$ & & \multicolumn{5}{|l|}{$<.05$} & \\
\hline
\end{tabular}

Source: Researcher's Field work 2019

The findings on statements relating to the types of contestants involved in vote buying were summarized in Table 8. It was noted that majority of the respondents $(70.4 \%)$ were in agreement with the statement that presidential contestants and or supporters are the usual vote buyers, $11.1 \%$ were not specific with their response, while $18.5 \%$ negated it. It was also observed that $71.1 \%$ of the respondents were in support of the statement that gubernatorial (Governorship) contestants and or supporters are the usual vote buyers, $14.5 \%$ were not certain in response, while $14.5 \%$ negated the view. Majority of the respondents $(61.6 \%)$ affirmed the statement that house of assembly contestants or supporters are the usual vote buyers, $20.2 \%$ were not specific with their response, while $18.2 \%$ felt contrary. On another statement, it was indicated that $65.4 \%$ of the respondents supported the statement that senate contestants or supporters are the usual vote buyers, $19.2 \%$ were indecisive, while $19.6 \%$ negated the statement. With the majority perception, it was noted that House of Representatives' contestants or supporters are the usual vote buyers. This was such that $65.4 \%$ supported the statement, $16.8 \%$ were indecisive, while $17.8 \%$ felt otherwise.
Further observations on related items revealed that majority of the respondents $(62.6 \%)$ of the respondents supported the statement that said Local Government Chairmanship contestants are or supporters are the usual vote buyers, $18.2 \%$ were indecisive, while $19.2 \%$ negated it. Also, $65.7 \%$ of the respondents were in support of the perception that Local Government councillorships contestants are or supporters are the usual vote buyers, $16.5 \%$ were indecisive, while $16.8 \%$ felt otherwise. Lastly, it was noted that $60.2 \%$ of the respondents affirmed the statement that said contestants and or supporters during primary election (internal party elections) are the usual vote buyers, $14.8 \%$ were not certain with their response, while $24.9 \%$ felt otherwise.

These results revealed that all the contestants were involved with vote buying during electoral processes. The average summary proved that $64.7 \%$ of the respondents confirmed the buying of votes buy the various forms of contestants, $16.5 \%$ were indecisive, while $24.9 \%$ felt contrary. Mean ranking was utilized to rank the items and identify the most form of contestant involved with vote buying and the chi square result indicated that the mean ranking was significant with $\mathrm{X}^{2}$ 
value of 95.325 , df of 7 and a p value that was less than 0.05 level of significant. Therefore, observations on the mean ranking revealed that vote buying is mostly observed with gubernatorial contestants $(\mathrm{M}=5.13)$. This was followed by the presidential contestants with a mean ranking of 5.04. The house of assembly contestants came next in ranking with a mean score of 4.41, followed by the Local Government chairmanship $(\mathrm{M}=4.38)$. The senate contestants and House of
Representatives' contestant were ranked next with a mean score of 4.29 each. The next ranked sets of contestants were contestant or supporters during primary election (4.24), while the least was among the Local Government chairmanship contestants or supporters $(\mathrm{M}=4.38)$.

Research Question 5: What are the outcomes or consequences of vote buying?

Table-5: Frequency, Mean ranking and Chi Square showing the outcomes or consequences of vote buying

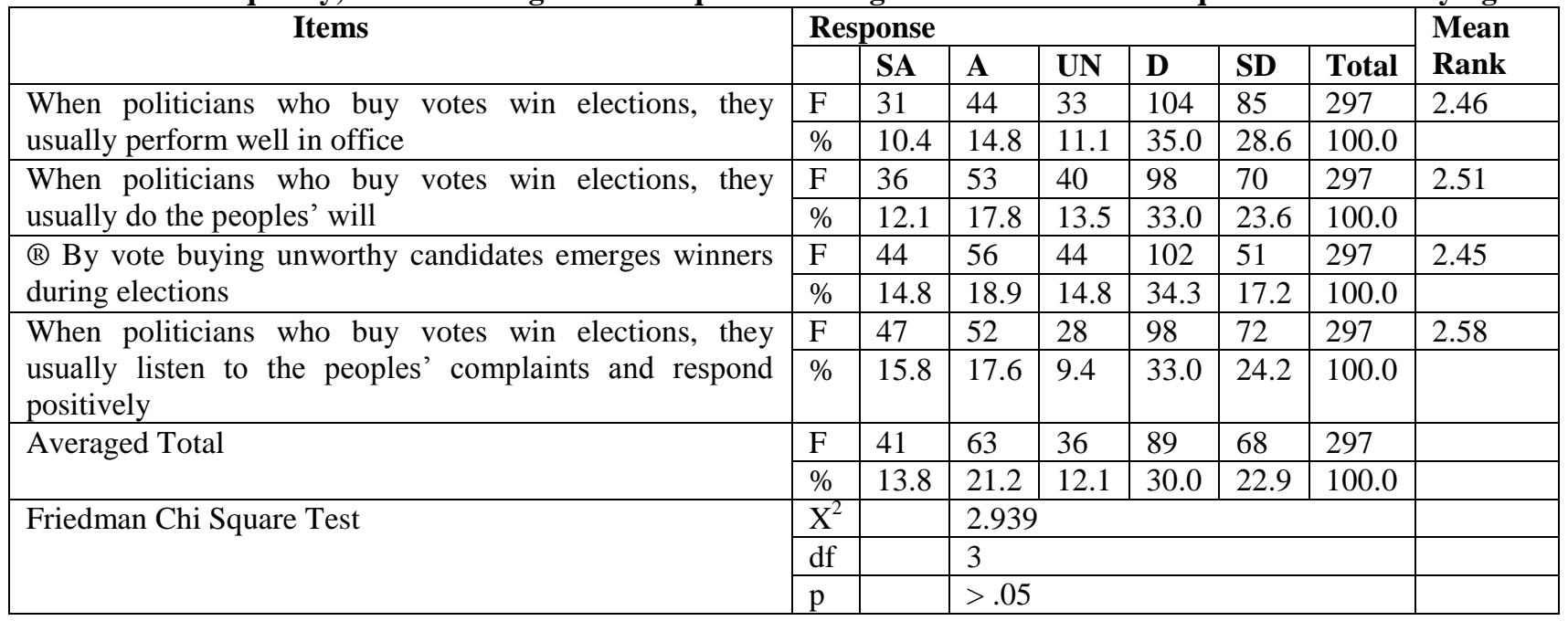

Note $®$ items were recorded for average summary.

Source: Researcher's Field work 2019

Testing the responses on outcomes of vote buying, it was observed that there was no significant difference in the ranking of the items based on their relevance with the research question. This was justified with the chi square value such that the observed $\mathrm{X}^{2}$ value of 2.939 at df of 3 was greater than 0.05 level of significant. This means that all items were equally rated. Explaining the items, it was observed that majority of the respondents $(45.4 \%)$ negated the statement that said when politicians who buy votes win elections; they usually perform well in office, $11.1 \%$ gave an uncertain response, while $43.4 \%$ supported the statement. Also, $41.4 \%$ of the respondents did not agree with the statement that said when politicians who buy votes win elections, they usually do the peoples' will, $13.5 \%$ were indecisive, while $45.1 \%$ supported it. On a different view, $49.1 \%$ of the respondents supported the statement that said by vote buying unworthy candidates emerges winners during elections, $14.8 \%$ gave an equivocal response, while $36.1 \%$ negated it. Lastly, it was observed that most of sampled respondents $(57.2 \%)$ were not in support of the statement that said when politicians who buy votes win elections, they usually listen to the peoples' complaints and respond positively, $9.4 \%$ were indecisive, while $33.4 \%$ supported it.

The average summary proved that most of the sampled respondents summited that vote buying leads to negative consequences and incredible leadership in the government. This was such that $52.9 \%$ negated the idea that vote buying could leads to positive outcomes, $12.1 \%$ were indecisive, while $35 \%$ supported the view. This implied that the outcomes of vote buying are negative.

\section{DISCUSSION OF FINDINGS}

The above position is supported by Nwankwo [25] in his paper "Vote Buying in the 2018 Governorship Election in Ekiti State, Nigeria". As monetized as the 2007 general elections were, as reported in the press, voters were paid as high as 2000 naira. However, in the just concluded Ekiti election, voters were paid as high as 10000 naira representing $500 \%$ increase in the value of a vote from 2007. An online news media, Pulse, quoted an aggrieved voter as saying "PDP middlemen are distributing N3,000 instead of N5,000" [25] implying that the voter is displeased by the amount the PDP is offering. Thus, the election was like an auction market where the highest bidder buys the good. What we have presently is democracy for sale - a democracy that perpetuates ignorance, poverty, violence and underdevelopment. This ugly trend is entrenching the practice of corrupting the system to earn illicit money in order to buy votes from an impoverished and psychologically-damaged populace. This leads to politicians offering bad governance, gaining illicit wealth in the process and repeating the cycle [25]. An investigation by one of the leading newspapers in Nigeria, Sun indicates that the two major 
political parties in the election, the PDP and APC took part in vote buying. The reporter of the (Omipidan, 2018, Sunday Sun, 15 July 2018) [26]. Ismail Omipidan notes that, An average Ekiti voter yesterday became instantly rich. Depending on who the voter must have cast his/her ballot for, the least an average voter got was $\mathrm{N} 2,500$. And this happened in Isan-Ekiti. If those who got the N2,500 had benefited the initial N4,000 from the other party, the voter would have smiled home with N6,500. But in Oye Ekiti, where one of the parties began with $\mathrm{N} 7,000$ per voter, before raising it to $\mathrm{N} 10,000$, which was only delivered to the voter after casting his/her ballot, such a voter would go home with between $\mathrm{N} 14,000$ and $\mathrm{N} 11,000$ if the voter had benefited from the other party's N4, 000 which was distributed a day to the election (Omipidan, 2018, Sunday Sun, 15 July 2018) [26]. The manifestation of a high level of vote buying is evident in the 2018 election result compared with the 2014 election.

As Fig-1 below indicates, the margin between the winner party and the loser party was more extensive in 2014 than 2018. In 2014, the PDP scored 57.97\% of the total valid votes while APC scored $34.37 \%$ and other political parties combined have $7.66 \%$. The margin between the two major parties is $23.6 \%$. In 2018, the APC scored 51. 34\% of the total valid votes while the PDP scored $46.31 \%$ and other political parties combined have $2.34 \%$. The margin this time is $5.03 \%$, also notice that the margin of voters supporting the minority parties declined by $5.32 \%$. So, we can see that the election was very competitive. And this attested to the impact of merchandisation of votes by the political gladiators.

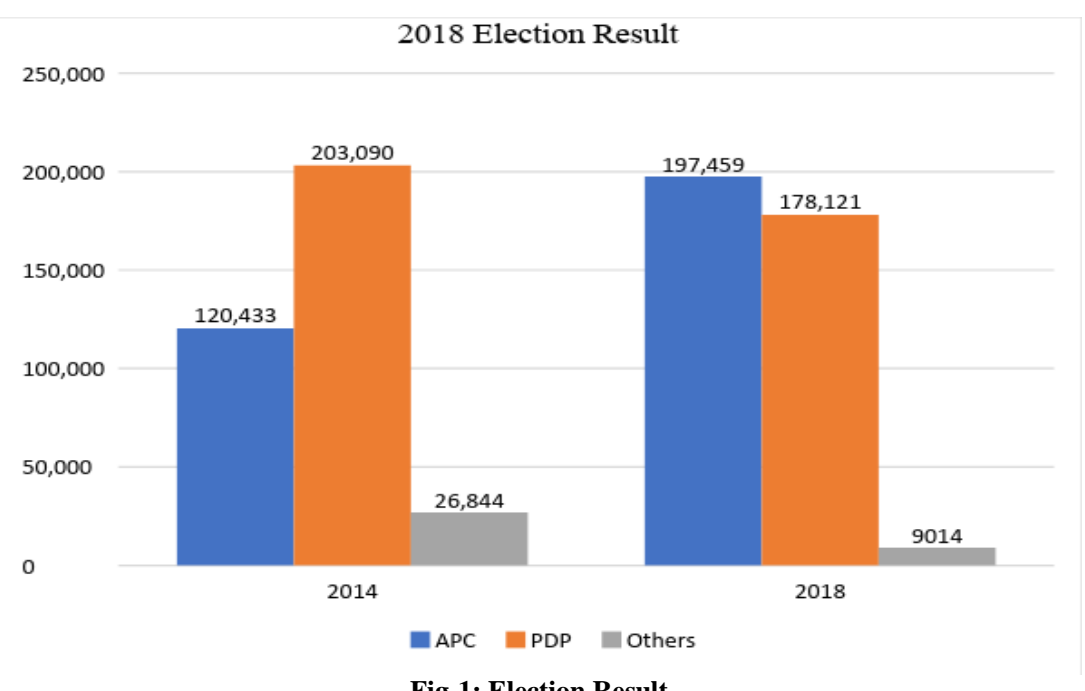

Sources: Channels Television (2018) and INEC (2014); Nwakwo [25]

Therefore, in juxtaposition with 2014, it can be argued that the competitiveness of the 2018 election is a manifestation of vote buying since the two major parties appealed for votes using money as rewards for people who voted the parties.

YIAGA AFRICA Initiative [6] in its comprehensive study on the Ekiti 2018 governorship election reports that the study reveals the following as drivers of vote buying and selling in Ekiti state:

\section{Poverty and Hunger}

The twin challenge of poverty and hunger was a major factor driving of vote buying and selling in Ekiti state. When households lack means to basic subsistence; the law of exigency takes charge resulting to compromised electoral behaviors such as vote buying and selling. For instance, available data from the Nigerian Bureau of Statistics (NBS) showed that more than $70 \%$ of Nigerians live below the poverty line of US\$ 1 dollar per day (specifically 112 million live in relative poverty); infant and child mortality rate is one of the highest in world (75 and 88 per 1,000 live birth); under five mortality is 157 per 1,000 live birth; maternal mortality is 545 deaths per 100,000 live births; electricity consumption is 50 percent; access to improved water is 56 percent; improved toilet facilities is 27 percent (NDHS, 2008; The Punch, 2012); the gap between the rich and the poor in terms of income inequality (increase from 0.429 in 2004 to 0.447 in 2010) continues to widen. It is also paradoxical to note that despite the fact that the Nigerian economy is growing at $7.7 \%$ due to its natural and material resources, the proportion of Nigerians living in poverty is increasing every year.

\section{Improved checks and balances in the electoral process}

The integrity of the electoral commission and introduction of technology and new innovations to the electoral process has deepened the integrity of elections in Nigeria. These improvements have made outright rigging unattractive for desperate politicians. Politicians resorted to vote trafficking as a strategy of compromising the electoral process. 


\section{Non-payment of workers' salaries, pensions and allowances}

Nonpayment of several arrears of salaries and emoluments of workers and pensioners in a civil service economy accounts for why many voters could not resist the offer of cash to sell their ballots during the election. Many workers and pensioners could not meet their domestic obligations.

\section{Failure of political officeholders to fulfil previous campaign promises}

The failure of past political officeholders to fulfil their campaign promises encouraged prospective voters to demand for cash before casting their ballot for individuals or political parties. Many voters were with the wrong orientation that you could only get your share of the National cake from the politicians during elections when they are humble enough to beg for your votes citing examples of past neglect by politicians that got their votes free of charge.

\section{Neglect of Rural Communities in the even distribution of infrastructural facilities}

The state government either deliberately or due to paucity of funds neglected many rural communities in the provision of basic amenities. The government concentrated development efforts at the centre of attraction (state capital). Communities opted to sell their votes to avert what they termed 'double tragedies' in case they are neglected by a new administration or political leadership.

YIAGA AFRICA Initiative [6] also identifies Methods and Dynamics of Vote Buying in Ekiti state. Different methods were deployed for the purchase of votes during the 2018 governorship election in Ekiti State among which are:

1. On-Line Transaction: Many prospective voters who work and receive salaries from the state government were credited with \#3,000 as stipend at the eve of election. Also, unemployed youths numbering over 30 thousand were credited with various amount ranging between $\# 2,000$ and \#3,000 each as mobilization from the state government, all with a view to influencing their choice of candidate.

2. Various gifts and food items were also distributed by different political parties' weeks/days before the election to woo voters.

3. Suspicious empowerment programmes were carried out prior to the election such as purchase of free JAMB Forms, grading of communities and farm roads, distribution of "empowerment" items like hair dryers, washing machines, power-generating machines to different individuals and groups with a view to securing their support and vote on election day.
4. Impersonation of election observers by party agents: Some party loyalists acted as election observers with observers kits from INEC. This gave them free access to monitor the distribution and deployment of their cash for the purchase of vote at every polling booth.

5. Collection of tally from party canvassers: In some polling booths, the pay agent is far away at a hidden location. The voter who is authenticate to have voted for the party is given a tally to collect the agreed sum.

6. As a means of authentication, some voters use camera phones to snapshot their ballot papers with a view to claiming the money promised them before casting their vote.

7. In some places, special agents (canvassers) were at hand to whisper to prospective voters in queue to vote for a particular party and thereafter collect money.

There was a mutual agreement between the voters and the buyers because both parties were willing Party members (canvassers) moved round the communities a day before the election/election day to give money to party members and "trusted" neighbors.

Voters seem to haven completely lost confidence in successive leaders at all levels of governance (either executive or legislative arm, state or local government). This trust issue permeated all discussions with our respondents. Proceeds from the election bazaar also had direct bearing on the economy. In many communities as affirmed by the respondents, markets were filled up by residents to buy foodstuff a day/2days after the election. In some polling units, the amount given varied. This was based on the availability of funds proportional to the number of voters that showed up and it was determined by the canvassers (ranging from 5 thousand (5000) naira to 2 thousand (2000) naira). However, in many of the polling units, the principle of equality was applied in respect of "commoditization" of vote. Betrayal of trust on the part of the canvassers who, as found out during the field work, diverted the amounts given to them just when many voters began to complain of not being financially compensated. This actually necessitated the variation in payment made as earlier indicated.

"Foreign" registrants, most especially students of higher institutions of learning (non-indigenes) were recruited for voter registration purposes prior to the election. Some were suspected to have come back during the election as attested to by some respondents especially in Ise/Orun LGA.

In the final analysis, the study contends that resolving the issue and reversing the trend may involve general economic empowerment of voters (citizens), far more than and beyond casual tinkering with modalities of voting and improving balloting secrecy by the 
authorities. It will take good governance, legal enforcement, prioritization of employment generation, restoration of ideological base for political parties, holistic war on corruption, and effective poverty reduction as policy options towards reversing and remedying the ugly trend.

\section{SOCIO-POLITICAL ECONOMIC IMPLICATIONS OF MACHANDISATION OF VOTES IN EKITI VIS-À-VIS IN NIGERIA AT LARGE}

Merchandisation of votes in Ekiti state is not without its attendant socio-political and economic implications. Nwankwo [25] identifies the following as implications of the manifestation of vote buying in the Ekiti election for the 2019 general election and beyond is that it will undermine political legitimacy and make a mockery of Nigerian democracy. It will create a fundamental problem of unaccountability and irresponsibility as the voters will not have the moral ground to demand good governance from politicians and it will affect the credibility of the elections.

Vote buying increases the outlays of elections for candidates and parties and may preclude dependable aspirants from contesting for political office. It generates disparagement among voters, with a sense of alienation from a besmirched system that nosedives democratic principles [27]. Consequently, there is a need for an essential check to this electoral menace, strengthening the electoral statutory framework is imperative. The incident of vote buying in the 2018 Ekiti governorship election might be a signal that Nigerian democracy is at a critical juncture for another massive electoral manipulation similar to the 2007 election.

Another major implications of vote buying is that it can trigger corruption by politicians after they are voted into power. This is because they would want to get return on money invested during election campaigns. This can lead to the abuse of state resources. The use of incentives to buy votes may have repercussions on elections. It can negatively impact the quality (freeness and fairness) of elections. Vote buying can contribute to the wrong political parties being elected to serve the nation. Once voters are paid to cast their votes in a certain way they become enslaved by their political paymasters as, by default, their rights to challenge their vote buying political paymasters are restricted. As vote buying is so widespread, it raises concerns about the quality of emerging democratic institutions and how potential elections conducted will help to deliver better and more accountable governments.

Concretely, merchandisation of votes with the use of incentives to buy votes the power of the ordinary citizen is gradually being sold to the rich politicians who may decide who wins an election in the country.
Conjunctively, merchandisation of votes will continue to widen the gap between the governors and the governed in the sense that, funds for developmental projects and infrastructure will be used to prosecute elections and therefore impact on the performance of the elected officials when they get to power. The attendant implication is that of poor road network, dilapidated public structures, unemployment, and lack of basic amenities and generally poverty is aggravated.

\section{RECOMMENDATIONS AND CONCLUSION}

Vote buying is a threat to the conduct of fair elections and it has remained rampant because of the abundance of weak parties and self-serving politicians unable to deliver on their campaign promises. The danger this poses lies in the fact that citizens, especially the poorest and most marginalized, can rely on cashfor-vote as the one and only dividend they are entitled to. As a product of deep-seated socioeconomic factors, there is no doubt that reversing the ugly trend of vote buying and the monetization of electoral processes in Nigeria is a herculean one that will require strategic remediation of its underlying root causes. Cash for vote, which represents a bane upon good governance and credible electoral conduct, is a condemnable scheme by contenders in an election of securing victory over rivals. While it may be difficult to eliminate this nascent phenomenon, it is very possible to minimize its negative consequences on the Nigerian polity through certain policy measures, as a way to assure free, fair, credible and transparent elections in Ekiti [6].

The following factors must be addressed in order to reverse the scourge of vote buying:

\section{Behavioral and attitudinal change}

Loose and undependable as it may be able to recommend attitudinal changes, it is the best measure against the ill of vote purchase and any other electoral malfeasance for that matter. With right attitudes, rigging, votes buying/inducement, alongside possible other electoral infractions cannot succeed. When the electorates have the right attitude and perception towards politics, they are rise above petty tendencies that make them susceptible to want on inducement at polling booths. Candidates with genuine purposes and right, operable manifestoes will get attracted to spaces of contests.

\section{Reducing the perquisite of public office}

Political positions should be made less attractive by reducing perquisites that await successful candidates. Virtues and values of probity, accountability, transparency and genuine brotherly feeling must be built into positions, such that profit to self is reduced, while the primacy of service to humanity is promoted. 


\section{Economic Empowerment}

Economic empowerment program that lift citizens out of poverty is required to stem the tide of vote buying and selling. Through robust policy frameworks that free the economic space for people to earn decent living without submitting to un-dignifying offers of political candidates, the electorate are fundamentally empowered and encouraged to partner in the process of ensuring electoral transparency, rather than leaving such to INEC, or getting them coerced by security agents during exercises.

\section{Poverty Eradication or Reduction Programmes}

The egregious impact of poverty cannot be overestimated. There is no gainsaying the fact that poverty plays a major role in creating the economic atmosphere for voter inducement and vote-buying to thrive as revealed in our findings. The nexus between poverty and elite manipulation and control of the masses leads one to a possible hypothesis that there may be a witting plan to impoverish followers in order to maintain and sustain political control. It is important therefore, that effective and sustainable poverty reduction strategies be put in place to assuage the influence of hunger and starvation in electoral decision making.

\section{Total and Comprehensive War on Corruption}

The war against corruption and corrupt official and individuals must be total. The war must not only be fought, but must be seen as fought. Corruption is a societal challenge that manifests in every facet of national life in Nigeria. It concerns conducts by the giver and the taker of inappropriate inducement as is the case with perpetrators of vote buying. Electoral laws must accommodate the various loopholes for corruption in the conduct of elections and see to the discharge of adequate punishment to offenders.

\section{Restoration of Ideological Bases for Political Parties Political parties are founded on clear manifestoes and programmes. These must be strictly adhere to. Political parties presuppose the existence of a uniting worldview for members of same political parties. To offer a clear platform for citizens' electoral decision making, political parties must embrace codified ideological perspectives that encapsulate their programmes and policy directions.}

\section{Provision of Gainful Employment to Enable Reversal of Rising Unemployment}

People are wont to sell whatever they have to get what they want. The rising monster of unemployment must be cut down before the total collapse of the system. Without which, the political system, the country is sitting on the keg of gun powder. Revolution is imminent. The challenge of unemployment has been thoroughly debated as a national menace in Nigeria with effects touching on virtually all facets of national life from security to election credibility. To insulate the youth from manipulation, opportunities for employment and productive engagement must be enhanced.

\section{Good Governance}

The imperative of good governance to development cannot be overemphasized. The quality of leadership is critical to its capacity for effective, people oriented and developmental decision making. "If all of the money spent to buy votes are pumped into the economy of the state, they would have been able to pay salaries. There will be prompt payment of salaries, jobs will be available and poverty will leave the state [6]." Also, when the political class embraces the idea of selfless services by implementing the manifestoes of their various parties to the benefits of the people, the menace of commercialization of ballot in the state will drastically reduce.

\section{Improved Management of Election Security}

Security agencies involved in elections must demonstrate commitment to electoral integrity and transparency through effective and objective management of election security. Security agencies should also intensify efforts in arresting and prosecuting electoral offenders.

Introduction of electronic voting system: Introduction of electronic voting could potentially reduce incidence of voting buying and selling in elections.

1. Implementation and Enforcement of electoral laws: A corollary of good governance is the introduction of stringent laws and effective implementation and punitive systems capable of dissuading potential offenders and sanctioning perpetrators [6].

2. Socio-political education: All the governmental institutions as National Orientation Agency (NOA), ministry of Information and value orientation should awake to their responsibilities by educating the citizenry about the cost effect of merchandisation of votes in the polity.

3. Electoral education: This is a corollary of the above, electoral education should be introduced as part of curriculum in the primary and secondary and even in the tertiary institutions. As this will enable the citizens to understand the values of elections and its impacts on their sociopolitical lives.

4. Empowerment of the civil societies and Non-Governmental Organizations (NGOs): virile and enabled environment should be given to the civil societies and NGOs to serve 
as a watchdogs on the government and the political parties activities.

\section{Free and Independent Press}

The importance of free press cannot be overemphasized in any democracy, therefore, they are to be free to carry out their duties and to watch and report the activities of the government and the political parties. They are also to be independent of the control of the government and politicians and political gladiators. It is axiomatic that who plays the pipe, dictates the tune.

\section{Institutionalization and criminalization of Merchandisation of votes}

Institutional reform is most needed to avert impending political and electoral crisis. The Nigerian democracy has progressed to a reasonable extent regarding curtailing election rigging since 2011, however, vote buying remains a bane to the progress being made. Therefore, as path dependence theorist argue there is a need for institutional reform at this critical juncture to check vote-buying ahead of the 2019 general elections. A further amendment to the electoral act is imperative to outlaw and criminalize vote buying and selling including any person or group aiding it. Besides, there is a need to improve the enforcement mechanisms of the law to tame the tides of vote buying and selling.

There is no doubt that Nigeria has made significant gains in enhancing the legal framework to guide against vote buying through the Electoral Act. However, there is the need to address some of the notable inconsistencies and potential loopholes in the law to curb the act, which drives up the costs of elections for parties and candidates as well as prevents credible candidates from running for political offices.

One of the most potent strategies is the enforcement of the electoral act provision on the maximum amount on possible campaign budgets of seekers of elective offices; a move which will immediately limit not just access to cash but even the freedom to dispense such. Indeed, parties and candidates will need to commit funds on printing manifestoes, purchasing office stationeries and equipment, running jingles and adverts, and logistics of movement for officials. But how strictures of transparency and accountability can be imposed, even in the process of ensuring all these, may be another task altogether. Thus, for those who elect to discountenance existing regulations on campaign spending, overshooting limits and limitations, consequences of infractions must be imposed on offenders. The problem in Nigeria has not always been absence of laws and regulations to countervail deleterious conducts, but the looseness of enforcement in such a way that what is made sauce for the goose is not always made sauce for the gander. While stiff punishment for rigging may be a solution, such can have meaning only if the enabling legal/judicial system is such that justice is served all the times. Law must apply to culprits, irrespective of socalled name, status or location. Such a target requires genuine alertness and cooperation of entire parties, including the government, the electoral commission, the political parties, the candidates, the electorate, the civil society and even the press.

Vote buying is an external pressure on voters which is prevalent in Nigeria. Indeed, the problem of vote-buying remains a threat to democracy in the country as it poses serious challenge to free and fair elections and the legitimacy of political office holders. Although the effect of voter inducement on election outcomes is yet to be scientifically determined, there is a moral burden on the managers of the election process in Nigeria regarding the credibility of elections in which voters are seen to have been induced by financial exchanges. A second effect of the scourge bothers on the question of accountability as citizens' role in the democratic election process. The task of holding leaders to account is one of the logic behind the voting power of the masses and relies on the trust between the electorate and elected leaders. This power is undermined where vote-buying is used to secure victory at the polls. Thus, this study examines issues surrounding political behaviour and par ty politics in Ekiti State with particular focus on vote buying as an emerging challenge to elections in the state. It is concluded that for any democratic nation to attain development, its systems of leadership selection or election must be full-proof of corruption and other forms of rigging like vote buying. Once citizens have formed their voting preferences, they must be allowed to freely express them on Election Day without any encumbrance or inducement. The study therefore recommends good governance, legal enforcement, prioritization of employment generation, restoration of ideological base for political parties, holistic war on corruption, and effective poverty reduction as policy options towards reversing and remedying the ugly trend [6].

\section{REFERENCES}

1. Agagu, A. A. (2004). The Nigerian state and Development: a theoretical and Empirical Exploration in Agagu, A. A., \& Ola, R. F. (eds), Development Agenda of the Nigerian state, FIAG (Nigeria) publishers, Ibadan.

2. Osaghae, E. E. (1998). The Cripple Giant: Nigeria since Independent. London: Hurst and Company.

3. Ayittey, G. B. N. (1992), Africa Betrayed, New York: St. Martins Press.

4. Oluwasuji, C. O. (2010). Nigeria's Underdevelopmental Crisis: Unending issues and Prospect in Akungba. Journal of Management, 2(1):40-50.

5. Jackson, J. R., \& Jackson, D. (2008). An Introduction to Political Science: Comparative 
and World Politics; fifth Election; Toronto: Pearson, Practice Hast.

6. YIAGA AFRICA Initiative. (2018). DULY ELECTED OR DULY PURCHASED? Report on Vote Buying and Selling in the 2018 Ekiti Governorship Elections; YIAGA AFRICA Initiative, August, 2018.

7. Piattoni, S. (Ed.) (2001). Clientelism, Interests, and Democratic Representation: The European Experience in Historical and Comparative Perspective. New York: Cam-bridge University Press.

8. Stokes, S. C. (2007). Political clientelism. In Boix C., \& Stokes, S. (Eds.), Handbook of comparative politics. Oxford: Oxford University Press. Aidt, Asatryan.

9. Aidt, T., Zareh Asatryan, Z., Badalyan, L., \& Heinemann, F. (2015). Vote Buying or (Political) Business (Cycles) as Usual?; Download this ZEW Discussion Paper from our ftp server: http://ftp.zew.de/pub/zew-docs/dp/dp15017.pdf

10. Baidoo F. L., Dankwa, S., \& Eshun, I. (2018). Culture of Vote Buying and its Implications: Range of Incentives and Conditions Politicians offer to Electorates. Published by European Centre for Research Training and Development UK, 6(2):1-20.

11. Schaffer, F. C., \& Schedler, A. (2005). What is vote buying? The limits of the market model"; Paper presented at the Conference of Poverty, Democracy and Clientelism: The Political Economy of Vote Buying, Stanford University.

12. Hicken, A., Leider, S., Ravanilla, N., \& Yang, D. (2018). Temptation in vote-selling: Evidence from a field experiment in the Philippines. Journal of Development Economics, 131, 1-14.

13. Oyinloye, B. A., \& Oluwasuji C. O. (2015). Elections, Representation and Voting Behaviour; in Robert, F. O., Ademola, I. A., \& Emmanuel, A. A. (ed.). Fundamentals of Politics; Lagos, Emboss Foyo.

14. Peter, M., \& Obi, A. (2014). Security, Human Rights and Elections in Nigeria: A Retrospective Analysis of the Militarization of 2007 General
Elections. Afro Asian Journal of Social Sciences, 4(4).

15. Ginsberg, B. (1982). The Consequences of Consent: Elections, Citizen Control, and Popular Acquiescence (Reading, MA: Addison-Wesley).

16. Heywood, A (2007). Politics; third edition; New York: Palgrase Macmillan.

17. Harris, R. (1975). The Political Economy of Africa, Cambridge, Massachusetts: Schenkman Publishing Company.

18. Marx, R. E. (1983). A new concept in the treatment of osteoradionecrosis. Journal of Oral and Maxillofacial Surgery, 41(6), 351-357.

19. Mimiko, N. O. (1998). Marx and Peripheral Social Formations: The Significance of the Political Economy Approach (PEA). In The Nigerian Journal of the Social Sciences; Nigeria: Ondo State University, Ado- Ekiti, 11(1).

20. Ake, C. (1986). Theoretical Notes on the National Question in Nigeria, Paper Presented at the National Seminar on the National Question in Nigeria, Abuja, 4-9.

21. Anikpo, M. (2002). Social Structure and the National Question in Nigeria. In Momoh, A., and Adejumobi, S. The National Question in Nigeria: Comparative Perspective, England: Ashgate Publishing Company.

22. Coleman, J. (ed.), (1986), Individual Interests and Collective Action: Selected Essays; Cambridge: Cambridge University Press.

23. Zafirovski, M. (1999). What is really Rational Choice? Beyond the Utilization Concept of Rationality. Current Sociology, 47(1), 47-113.

24. Mbaku, J. M., Agbese, P. O., \& Kimenyi, N. S. (2001). Ethnicity and Governance in the Third World, England: Ashgate Publishing Limited.

25. Nwankwo, C. F. (2018). Vote Buying in the 2018 Governorship Election in Ekiti State, Nigeria, open political Science, 93-97.

26. Omipidan, 2018, Sunday Sun, 15 July 2018.

27. Matenga, G. (2016). Cash for Votes: political legitimacy in Nigeria. Open Democracy, Available at: https://www.opendemocracy.net/grammatenga/cash-for-votes-political-legitimacy-innigeria Retrieved 17 July 2018. 